\title{
THE PATTERN OF SNACK AND BEVERAGE CONCUMPTION FOR SUKU ANAK DALAM (SAD) CHILDREN IN THE TRANS SOCIAL AREA OF NYOGAN VILLAGE, MUARO JAMBI, JAMBI PROVINCE
}

\author{
Hendra Dhermawan Sitanggang, Ummi Kalsum
}

Public Health Study Program, Universitas Jambi

\begin{abstract}
Background: Consumption of street food in school has an impact on children's health, especially their nutritional status. Children in the Anak Dalam Tribe (SAD) are mostly malnourished and short. The remote indigenous community (Suku Anak Dalam) in Nyogan Village has undergone a social transition for 15 years since being granted permanent settlement by the Government. Many changes have occurred as well as consumption patterns. This study aims to determine the pattern of consumption of street food and beverages in schools for SAD children in Nyogan Village.

Subjects and Method: This was a qualitative study with a phenomenological design conducted in Nyogan Village, Muaro Jambi Regency. Several information was selected for this study included: children, parents, community leaders or traditional leaders, school principals, teachers, neighbourhood leader, village heads, village midwives and public health center officer. The inclusion criteria were consumption pattern of food and drink snacks for SAD children at school. The data were collected by in-depth interview and analyzed using Miles and Hubberman's model.

Results: Children with SAD who go to elementary school in trans social areas in Nyogan Village like food and drink snacks. The most commonly consumed snack foods are sausages, sticky and grilled meatballs, thousand fried rice, candy, rice cake. At the same time, the most widely consumed snack drinks are present ice, juice jacket, glass tea, okky jelly drink, and ice cream. The reason is that only these types of food and beverages are available and cheap. SAD children in Nyogan Village rarely eat local snacks, such as fried sweet potatoes, that used to be consumed. There are concerns regarding the safety of snack foods and drinks suspected of having "chemical content" that is harmful to children health in these snacks. The cleanliness of the place of snacks and personal hygiene of food handlers are factors related to food and beverage snacks' health. The Health Officer or public health center never conducts counseling on snack foods' safety and is not regularly supervised.

Conclusion: The consumption pattern of food and drink snacks for children with SAD in trans-social areas has changed. They consume snacks that are sold around the school. However, these foods and drinks are not guaranteed safety. Education and supervision are needed for food vendors or handlers in schools so that SAD children improve their health.
\end{abstract}

Keywords: Consumption patterns, school snacks, children's health, Suku Anak Dalam, qualitative

\section{Correspondence:}

Hendra Dhermawan Sitanggang. Program Studi Ilmu Kesehatan Masyarakat, Universitas Jambi. Jalan Tri Brata, Km 11 Kampus Unja Pondok Meja Mestong, Kab. Muaro Jambi. Email: hendrasitanggang@unja.ac.id. Mobile: 0813619180oo.

The $7^{\text {th }}$ International Conference on Public Health Solo, Indonesia, November 18-19, 2020 | 132 https://doi.org/10.26911/the7thicph.02.21 